\title{
Implementation The Act Against The Material Law In Act No. 31 of 1999 jo Act No. 20 of 2001 Concerning of Corruption Linked With Constitutional Court's Decision No. 003 / PUU / IV / 2006
}

\author{
Danceu $^{1}$
}

Abstract. The problem in this research are: (1) How is the location of the nature of the unlawful material law in Act No. 31 of 1999 Jo Act No. 20 of 2001 on the Corruption linked with Constitutional Court Decision No. 003 / PUU / IV / 2006?; (2) What is the nature of policy implementation against the material law in Corruption Act after the decision of the Constitutional Court Number 003 / PUU / IV / 2006? Research methods is descriptive analytical by using sociological juridical approach. The results of the study author shows that the nature of the unlawful material in Act No. 31 of 1999 Jo Act No. 20 of 2001 on the Corruption linked with Constitutional Court Decision No. 003 / PUU / IV / 2006 of the nature of the unlawful material, used as means the eradication of corruption in the Act No. 31 1999 Jo Act No. 20 of 21 declared non-binding with legal certainty (in violation of Article $28 \mathrm{D}$ Constitution 1845), implementation of a policy nature against the law material in Act of Corruption after the decision of the Constitutional Court Number 003 / PUU / IV / 2006 by the legislative arrangements do not exist anymore in the Law on Corruption Eradication.

Keywords: Personality Against Material Law; Corruption; Constitutional Court Decision.

\section{Introduction}

The development of civilization the world is getting a day seemed to run toward modernization. Developments always bring changes in every facet of life seem more real. Along with that, the forms of crime always follows the times and transformed into other forms of increasingly sophisticated and diverse. One crime that received special attention and complexity is corruption. ${ }^{2}$

Corruption is not something that is foreign to every society, even corruption is a perennial problem that must be faced by all nations in the world. But corruption is a criminal offense that is unique, multi-dimensional, and highly destructive to the society, nation and state. ${ }^{3}$ Law enforcement against corruption in Indonesia seemed stilted and even frequent stagnation that led to the negative image of the law enforcement agencies in particular and government in general. Legalistic approach oriented only repressive law is a powerful tool in combating corruption, it is necessary for a comprehensive approach is expected to found what became the main cause (causa prima) her, so that countermeasures can be

\footnotetext{
${ }^{1}$ Student of Master of Law, Universitas Islam Sultan Agung Semarang and State Attorney of Purwakarta email: istambul 79@yahoo.com

2 Romli Atmasasmita 2002 Korupsi Good Governance dan Komisl And Korupsi dl Indonesia Badan Pembinaan Hukum Nasional Departemen Kehakiman dan Hak Asasi Manusla Republik Indonesia Jakarta p. 25.

${ }^{3}$ Etty Indriati 2014 Pola Dan Akar Korupsi Menghancurkan Lingkaran Setan Dosa Publik PT. Gramedia Pustaka Utama Jakarta p. 1.
} 
adequately fulfilled corruption, sustainable and appropriate.

Realize a fair society, and prosperous, it needs to be constantly improved prevention efforts and eradication of the crime in general and corruption in particular. Act ever apply that Act No. 3 of 1971 and Act No. 31 of 1999 on combating corruption, which is expected to be able to meet and anticipate the development of the legal needs of the community in order to prevent and combat more effectively the form of a criminal offense corruption is very detrimental to the state finance and economy in particular and society in general are no longer suitable to the development of law in society. Based on these considerations, the ${ }^{4}$

Based on the background of the above problems, the problem can be identified as follows: What is the location of the properties unlawfully material in Act No. 31 of 1999 Jo Act No. 20 of 2001 on the Corruption linked with Constitutional Court Decision No. 003 / PUU / IV / 2006? How can policy implementation unlawful nature material in Corruption Act after the decision of the Constitutional Court Number 003 / PUU / IV / 2006?

\section{Research Methods}

This is a descriptive analytical study, which illustrates the problems that the object of research, and analysis of these issues. The method research approach is by using sociological juridical approach. Sociological juridical approach method is identified and conceived law as a social institution that is real and functional in a real life system

\section{Results and Discussion}

\subsection{Overview About Implementation of Unlawful Act in the Material Law of Corruption linked with Constitutional Court Decision.}

The word itself comes from the implementation of English "to implement" means to implement. Not just the activities, implementation is an activity planned and implemented seriously also refers to certain norms in order to achieve the objectives of the activity.

In other words the implementation as a provider of tools to accomplish something that causes an impact on something. Something is done so that raised serious effect of laws, regulations, judicial decisions and policies that have been made by government agencies in the state of life. ${ }^{5}$

The term comes from the law against the Dutch language is "wederrechtelijk". However, to know clearly understanding against the law (wederrechtelijk) is not enough to know only its literal sense. In other words, we should bear in mind clearly and deeply the meaning of the term against the law, we at least have to understand the terms above.

A general description of a criminal act is a human act that meets the formulation of the offense, fight-law and manufacturer guilty of the deed. Enschede puts it, "een strafbaar feit is een menselijke gedraging, die Valt binnen de Grenzen van een delictsomschrijving, wederrechtelijk is en aan Schuld tewijten." (A criminal act is an act of man, which is included in the formulation of the offense, unlawful and mistakes can be

5 https://alihamdan.id/implementasi/ accessed on 21-06-2018. 
harmed her). ${ }^{6}$

Talking about the criteria (a source of law or legal basis) what is used to set the base should punished an act as despicable (is against the law), in the literature of criminal law there are two (2) teachings. The doctrine in question is unlawful nature of the formal teachings and the teachings of the nature of unlawful material.

According to the nature of the formal opinion is against the law not always be an element of a criminal offense, only if expressly states in the formulation of criminal acts does it become criminal elements. Meanwhile, according to the opinion of the nature of unlawful material is an absolute element of any criminal offense, as well as for offenses in the formulation is not stated explicitly. ${ }^{7}$

The existence of the Constitutional Court Organization is a new phenomenon in the world of constitutional because most established democracies, does not recognize the institution of the Constitutional Court of its own. The functions that can be imagined as a function of the Constitutional Court as a judicial review in order to examine the constitutionality of the Act, both in the formal sense or in the sense of material, associated directly with the authority of the Supreme Court. ${ }^{8}$

One concrete form in the 1945 amendments are aimed at ensuring the enforcement of state laws is to establish new institutions, namely the Constitutional Court. The existence of the Constitutional Court in 2001 the third amendment of Article 24 of the 1945 Constitution states that the Constitutional Court together with the Supreme Court holds the power of the judiciary. ${ }^{9}$

The word corruption comes from the Latin word corruptio or Corruptus. It was also stated that it is derived from the word corruptio corrumpere. From the Latin word that fell into many languages such as English: Corruption, Corrupt; France: Corruption and the Netherlands: corruptie. From the Dutch word down into Indonesian be: Corruption. The meaning of the word is decay, ugliness, depravity, not honest, incorruptible, unscrupulous, deviating from the holiness, the words are insulting or defamatory. ${ }^{10}$

\subsection{Unlawful Material nature is connected with the Constitutional Court Decision No. 003 / PUU / IV / 2006}

The nature of Unlawful Material, there are several issues that need to be addressed properly, especially in implementing the policy yudikasi in law enforcement "in concreto" by the judge, in addition to qualified - formal requirements, which meet all of the elements contained in the formulation of the offense, the act must also be true - correctly perceived by the public as an act of improper or disgraceful.

In its decision, the Constitutional Court No. 003 / PUU / IV / 2006, to discuss a number of things, as proposed by Ir. David Djamiko an employee working at PT. Jasa Marga (Persero) Bogor, suspected of corruption in highway projects Taman Mini Indonesia Indah - Cikunir.

6 Enschede in Komariah Emong Sapardjaja 2002 Ajaran Sifat Melawan Hukum Materiil Dalam Hukum Pidana Indonesia Alumni Bandung p.23.

7 Noyon and Langemeijer 1972 in Wetboek van Strafrecht (KUHP) Bina Aksara Jakarta hlm.19.

8 Jimly Asshiddiqie dan Mustafa Fakhry Mahkamah Konstitusi: Komplikasi Ketentuan UUD UU dan Peraturan di 78 Negara Jakarta p.246.

9 Ibid p. 280.

10 Andi Hamzah 1984 Korupsi Dalam Pengelolaan Pembangunan Akademi Presindo Jakarta p.3 
Through his lawyer suspects filed an application pursuant to the authority of the Constitutional Court to undertake judicial review of Article 2 paragraph (1) and an explanation, Article 3 and its description, article 15 (All of the experiments) Act PTPK to Article 280 paragraph (1), in which the article contained teaching unlawful nature of the material and legal position.

Of those reasons and after hearing the petition and statement of the applicant, the government's statement (DPR), the parties concerned (Attorney KPK, Attorney Timtas TIPIKOR), and have read the written statement of the government, the written statements of the parties, expert statements and examine the evidences, the Constitutional Court in its decision (Decision No. 003 / PUU / IV / 2006), try the following:

- Granted the request of the applicant for most

- That the explanation of Article 2 (1) of Act No. 31, 1999, contrary to the 1945 Constitution and not legally binding.

- To order the publication of this decision in the Official Gazette of the Republic of Indonesia as it should be.

- Reject the application for the remaining applicants.

Size that can be used in this regard is the unwritten law. Sense of justice, obscenity and norms prevailing in society has been quite a criteria of the act was an act against the law, although only seen in the material.

Elucidation of Article 2 (1) has created a new norm, which includes the use of size - the size is not written in the law formally to determine the act can be imprisoned.

According to Andi Hamzah, that the concept of Unlawful Material which refers to the unwritten law in the size of propriety, prudence and austerity of life in society as a norm of justice is a measure of uncertainty and different from other communities, so that what is against legal in one place may be in other places is accepted and recognized as legitimate, and not against the law, according to the size of the local community.

Of the presentation can be seen that according to the Constitutional Court against the law of the nature of the material, which is used as a means of combating corruption in the Act No. 311999 Jo Act No. 20 of 2001 declared non-binding with legal certainty (in violation of the Constitution Article 28 D 1845), which reads as follows:

- Everyone is entitled to recognition and protection guarantee legal certainty and equal treatment before the law

- Everyone has the right to work and to receive remuneration and fair and proper treatment in the employment relationship.

- Every citizen has the right to obtain equal opportunities in government.

- Everyone is entitled to citizen status.

\subsection{Implementation of Unlawful nature Policy Material In Act of Corruption After the existence of the Constitutional Court Decision No. 003 / PUU / IV / 2006}

Jurisprudence of the Supreme Court regarding the nature of the unlawful material is then post-discharge Constitutional Court Decision No. 003 / PUU-IV / 2006 dated 25 July 2006 which is the case for the existence of nature against the law especially in material sense that the legislative arrangements do not exist anymore the Law on Corruption Eradication. But in practice, the Supreme Court continued to recognize the existence of unlawful nature of the material. Whereas Decision of the Court in its Decision No. 003 / PUU-IV / 
2006 canceled the explanation of article 2, paragraph (1) of Act No. 31 of 1999 jo Act No. 20 of 2001.

But after the release of the Constitutional Court's decision that the Supreme Court of Indonesia in its Decision include:

- Supreme Court Decision No. 996 K / Pid / 2006 Date August 16, 2006 on behalf of Defendant Hamdani Amin;

- Supreme Court Decision No. 1974 K / Pid / 2006 Date October 13, 2006 on behalf of Defendant Rusadi Kantaprawira

- Supreme Court Decision No. 2064 K / Pid / 2006 Date January 8, 2007 on behalf of the defendant $\mathrm{H}$. Fahrani Suhaimi;

Continue to recognize the nature of the substantive law against these things can be seen in its consideration of the decisions of the Decision above with through legal interpretation and together with the following arguments:

- That the Constitutional Court Decision No. 003 / PUU-IV / 2006 dated July 25, 2006 roomates stated explanation of Article 2, paragraph 1 of Act No. 20 of 2001 jo No. 31 of 1999 on Corruption Eradication declared Contrary to Constitution in 1945 and has been declared not legally binding and is therefore an element of "unlawful" it has Become clear formulations, therefore, based on the doctrine of "Sen-Clair" or "La doctrine du Mon-Clair" judges must perform legal discovery. ${ }^{11}$

- That the starting point of the aspects mentioned above, the Supreme Court in interpretation element "unlawful" in the provisions of Article 2 (1) of Act No. 31 of 1999 jo Act No. 20 of 2001 on Corruption Eradication will pay attention to the doctrine and jurisprudence of the Supreme Court.

Then the definition of "unlawful" according to the explanation of Article 1 (1) sub a of Act No. 3 of 1971, not only violate existing regulations sanctions but also cover actions contrary to the necessity or propriety in the association community or is deemed reprehensible by society,

- That jurisprudence and doctrine is the formal legal source other than the Act and Customs and the Treaty that can be used by the Supreme Court in the case of concrete faces. Jurisprudence on the meaning of an unlawful act in formal sense and in the sense that the material should still be used as guidelines for building consistency of its application in cases of corruption, because it is in conformity with the legal awareness and legal sense of being alive in the community, the legal needs of citizens, values law and sense of justice in society. ${ }^{12}$

So that this results in obscurity and does not give a legal certainty. Because on the one hand in the legislative arrangements concerning the nature against the law in a material sense in corruption no longer known. But in practice, the Supreme Court continued to Recognize the existence of nature against the law in a material sense. Therefore, in the perspective of justice, the judge always confronted with a demand the which the judge may not refuse a case on the grounds there is no law regulates roomates or less clear.

\footnotetext{
11 Lilik Mulyadi 2008 Bunga Rampai Hukum Pidana: Perspektif Teoretis dan Praktis PT Alumni Bandung: 193.

12 Ibid. p. 194.
} 


\section{Closing}

\subsection{Conclusion.}

- The results of the study the author shows that the nature of the unlawful material in Act No. 31 of 1999 Jo Act No. 20 of 2001 on the Corruption linked with Constitutional Court Decision No. 003 / PUU / IV / 2006 of the nature of the unlawful material, used as means the Eradication of corruption in the Act - Act No. 311999 Jo Act No. 20 of 2001 declared non-binding with legal certainty (in violation of the Constitution Article $28 \mathrm{D}$ 1945).

- Unlawful material nature of policy implementation in Corruption Act after the decision of the Constitutional Court Number 003 / PUU / IV / 2006 by the legislative arrangements do not exist anymore in the Law on Corruption Eradication. But in practice, the Supreme Court continued to Recognize the existence of unlawful nature of the material.

\subsection{Suggestion.}

Based on the conclusion, the author can put forward suggestions as follows:

- Act No. 311999 Jo Act No.20 of 2001 on Corruption Eradication should provide clear criteria as to what is meant by-Laws Against Nature Materials, and Tus have legal certainty.

- The Constitutional Court should decide expressly stated function Which is not legally binding on the nature of the material against-law, whether negative or positive functions

\section{References}

[1] Andi Hamzah Korupsi Dalam Pengelolaan Pembangunan Akademi Presindo Jakarta 1984.

[2] Enschede in Komariah Emong Sapardjaja Ajaran Sifat Melawan Hukum Materiil Dalam Hukum Pidana Indonesia Alumni Bandung 2002.

[3] Etty Indriati Pola Dan Akar Korupsi Menghancurkan Lingkaran Setan Dosa Publik PT. Gramedia Pustaka Utama Jakarta 2014.

[4] Jimly Asshiddiqie and Mustafa Fakhry Mahkamah Konstitusi: Komplikasi Ketentuan UUD UU dan Peraturan di 78 Negara Jakarta.

[5] Lilik Mulyadi Bunga Rampai Hukum Pidana: Perspektif Teoretis dan Praktis PT Alumni Bandung: 2008.

[6] Marwan Effendy Kejaksaan Republik Indonesia Posisi dan Fungsinya dari Perspektif Hukum Ghalia Indonesia 2007.

[7] Noyon dan Langemeijer in Wetboek van Strafrecht (KUHP) Bina Aksara Jakarta 1972.

[8] Romli Atmasasmita Korupsi Good Governance dan Komisl And Korupsi di Indonesia Badan Pembinaan Hukum Nasional Departemen Kehakiman dan Hak Asasi Manusla Republik Indonesia Jakarta 2002.

[9] https://bppk.kemenkeu.go.id/id/publikasi/artikel/150-artikel-keuanganumum/20078-korupsi-menurut-hukum-islam accessed on 21-06-2018.

[10] https://alihamdan.id/implementasi/ accessed on 21-06-2018. 